PROCEEdINGS OF THF GEOLOGICAL SOCIETy. [June 4,

\title{
Conclusion.
}

After having observed the facts detailed in the foregoing paper, the author has arrived at the following conclusions:-

1st. That although the Lancashire coal-field is 6600 feet in thickness, and is probably the most perfectly developed coal-field in England, still it has never been seen to graduate upwards into the new red sandstone, and, consequently, that its upper boundary must be considered as unascertained.

2nd. That on comparing the Lancashire coal-field with that of the south-west of Yorkshire and Derbyshire, the latter exhibits a deficiency of 837 yards of the middle and upper measures.

$3 \mathrm{rd}$. That the new red sandstone formation is found resting upon coal-measures of all ages, and scarcely ever at different places on rocks of the same age, so that it cannot with propriety be said to bound, but only to cover them.

4th. That where coal-measures have been found on their rise outcropping against the new red sandstone, the latter bed, so far as has been yet proved, always indicates that the coal-measures exist beneath it, but that the dislocation is of great extent.

5 th. That in all cases where seams of coal have been followed on their dip under the new red sandstone, they have been found to continue under it without any perceptible difference either in their inclination or quality.

6th. That the dislocations in the coal-field may be classed under two heads, namely the older ones, produced before the deposition of the upper new red sandstone, and the newer ones which have been produced since, but that the former have been in some degree affected by the movements which produced the latter.

7 th. 'That the new red sandstone formation is very irregularly deposited over the underlying carboniferous strata, and that its two lower members are frequently either very slightly developed or altogether wanting, which seems to indicate that these lower members repose in great troughs and hollows of the coal-field, which had an irregular surface, over which the waters of the new red sandstone sea flowed and deposited the various beds.

JUNE 4, 1845.

The following communications were read:-

1. An account of the FINE DusT which often falls on Vessels in the Atuantic Ocean. By Charles Darwin, Esq., F.R.S., F.G.S.

MANY scattered accounts have appeared concerning the dust which has fallen in considerable quantities on vessels on the African side of the Atlantic Ocean. It has appeared to me desirable to collect these accounts, more especially since Professor Ehrenberg's remarkable discovery that the dust consists in considerable part of Infusoria and 
Phytolitharia. I have found fifteen distinct statements of dust having fallen; and several of these refer to a period of more than one day, and some to a considerably longer time. Other less distinct accounts have also appeared. At the end of this paper I will give the particular cases, and will here only refer to the more striking ones and make a few general remarks.

The phænomenon has been most frequently observed in the neighbourhood of the Cape Verd Archipelago. The most southern point at which dust is recorded to have fallen is noticed by Capt. Hayward $\left({ }^{1}\right)$, on whose vessel it fell whilst sailing from lat. $10^{\circ} \mathrm{N}$. to $2^{\circ} 56^{\prime} \mathrm{N}$; the distance from the nearest of the Cape Verd Islands being between 450 and 850 miles. Respecting the northern limit, the water for a great distance on both sides of $\mathrm{C}$. Noon (in lat. $\left.28^{\circ} 45^{\prime}\right)$ is discoloured, owing in part, according to Lieut. Arlett $\left({ }^{2}\right)$, to the quantities of falling dust. Hence the phænomenon has been observed over a space of at least 1600 miles of latitude. This dust has several times fallen on vessels when between 300 and 600 miles from the coast of Africa: it fell, in May 1840, on the Princess Louise $\left({ }^{3}\right)$ (in lat. $14^{\circ} 21^{\prime} \mathrm{N}$. and long. $35^{\circ} 24^{\prime}$ W.) when 1030 miles from Cape Verd, the nearest point of the continent, and therefore half-way between Cayenne in S. America and the dry country north of the Senegal in Africa.

On the 16th of January (1833), when the Beagle was ten miles off the N.W. end of St. Jago, some very fine dust was found adhering to the under side of the horizontal wind-vane at the mast-head; it appeared to have been filtered by the gauze from the air, as the ship lay inclined to the wind. The wind had been for twenty-four hours previously E.N.E., and hence, from the position of the ship, the dust probably came from the coast of Africa. The atmosphere was so hazy that the visible horizon was only one mile distant. During our stay of three weeks at St. Jago (to February 8th) the wind was N.E., as is always the case during this time of the year; the atmosphere was often hazy, and very fine dust was almost constantly falling, so that the astronomical instruments were roughened and a little injured. The dust collected on the Beagle was excessively fine-grained, and of a reddish brown colour ; it does not effervesce with acids; it easily fuses under the blowpipe into a black or gray bead.

In 1838 , from the 7 th to the 10th of March, whilst Lieut. James in H.M.S. Spey was sailing, at the distance of from 330 to 380 miles from the continent, between lat. $21^{\circ} 10^{\prime} \mathrm{N}$., long. $22^{\circ} 14^{\prime} \mathrm{W}$., and lat. $17^{\circ} 43^{\prime} \mathrm{N}$., long. $25^{\circ} 54^{\prime} \mathrm{W}$, considerable quantities of dust fell on his vessel, four packets of which, together with a written communication, I owe to the kindness of Mr. Lyell. The dust which fell on the first day (or the 7th) was preceded by a thick haze, and it is coarser than that which fell on the succeeding days: it contains numerous irregular, transparent, variously coloured particles of stone about the $\frac{1}{1000}$ th of an inch square, with some few a little larger, and much fine matter. The fact of particles of this size having been brought at least 330 miles from the land is interesting, as bearing on the distribution of the sporules of cryptogamic 
PROCEEDINGS OF THE GEOLOGICAL SOCIETY. [June 4,

plants and the ovules of Infusoria. The dust which fell on the three succeeding days resembles in appearance and in its action under the blowpipe that collected by myself off St. Jago, and is so excessively fine, that Lieut. James was obliged to collect it with a sponge moistened with fresh water. As the wind continued nearly in the same direction during the four above-mentioned days, and the distance from the land was only a little increased after the first day, it would appear probable that the coarser dust was raised by a squall with which the breezes on this coast so often begin blowing.

With respect to the direction of the wind during the falls of dust, in every instance where recorded it has been between N.E. and S.E.; generally between N.E. and E. In the case however given by the Rev.W. Clarke (4), a hazy wind which had blown for some time from E. and S.E. first fell calm, and was succeeded for a few hours by a S.W. wind, and then returned strongly to the east; during this whole time dust fell. With respect to the time of year, the falls have always occurred in the months of January, February, March and April; but in the case of the Princess Louise in 1840, as late as on the 9 th of May. In the one year of 1839, it has chanced that dust has been recorded as having fallen in the Atlantic (as may be seen in the references) on the 14th and 15th of January, and on the 2nd, 4th, 9th, 10th, 11th, 12th and 13th of February. I may add, that Baron Roussin $\left({ }^{5}\right)$, during his survey of the north-western African coast, found, that whilst the wind keeps parallel to the shore, the haze and dust extend seaward only a short distance; but when during the above four specified months the harmattan blows from the N.E. and E.N.E., accompanied by tornados, the dust is blown far out, and is raised on high, so that stars and all other objects within $30^{\circ}$ of the horizon are hidden.

From the several recorded accounts $\left({ }^{6}\right)$ it appears that the quantity of dust which falls on vessels in the open Atlantic is considerable, and that the atmosphere is often rendered quite hazy; but nearer to the African coast the quantity is still more considerable. Vessels have several times run on shore owing to the haziness of the air : and Horsburgh $\left({ }^{7}\right)$ recommends all vessels, for this reason, to avoid the passage between the Cape Verd Archipelago and the main-land. Roussin also, during his survey, was thus much impeded. Lieut. Arlett found the water so discoloured (s), that the track left by his ship was visible for a long time; and he attributes this in part to the fine sand blown from the deserts, "with which everything on board soon becomes perfectly caked."

Professor Ehrenberg * has examined the dust collected by Lieut. James and myself; and he finds that it is in considerable part composed of Infusoria, including no less than sixty-seven different forms. These consist of 32 species of siliceous-shielded Polygastrica; of 34 forms of Phytolitharia, or the siliceous tissues of plants ; and of one

* These microscopic organized bodies have been described in the "Monatsberichten der Berlin Akad. der Wissens. Mai 1844 ; u. 27 Februar 1845.' In the latter paper a full list of the names is given : the column marked St. Jago includes those collected by myself. 
Polythalamia. The little packet of dust collected by myself would not have filled a quarter of a tea-spoon, yet it contains seventeen forms. Professor Ehrenberg remarks, that as 37 species are common to several of the packets, the dust collected by myself, and on four successive days by Lieut. James, must certainly have come from the same quarter; yet nine was brought by a E.N.E. wind, and Lieut. James's by a S.E. and E.S.E. wind. The Infusoria are all old known species, excepting one allied to a Hungarian fossil ; and they are of freshwater origin with the exception of two (Grammatophora oceanica and Textilaria globulosa), which are certainly marine. Prof. Ehrenberg could not detect any of the soft parts of the Infusoria, as if they had been quickly dried up, and hence it would appear that they must have been caught up by the wind some time after having been dead. The greater number of the species are of wide or mundane distribution; four species are common to Senegambia and S. America, and two are peculiar to the latter country $:$ moreover it is a very singular fact, that out of the many forms known to Professor Ehrenberg as characteristic of Africa, and more especially of the Sahara and Senegambian regions, none were found in the dust. From these facts one might at first doubt whether the dust came from Africa; but considering that it has invariably fallen with the wind between N.E. and S.E., that is, directly from the coast of Africa; that the first commencement of the haze has been seen to come on with these winds; that coarser particles have first fallen; that the dust and hazy atmosphere is more common near the African coast than further in the Atlantic; and lastly, that the months during which it falls coincide with those when the harmattan blows from the continent, and when it is known that clouds of dust and sand are raised by it, I think there can be no doubt that the dust which falls in the Atlantic does come from Africa. How to explain the enigma of the absence of characteristic African forms and of the presence of two species from S. America, I will not pretend to conjecture. Finally I may remark, that the circumstance of such quantities of dust being periodically blown, year after year, over so immense an area in the Atlantic Ocean, is interesting, as showing by how apparently inefficient a cause a widely extended deposit may be in process of formation ; and this deposit, it appears from the researches of Prof. Ehrenberg, will in chief part consist of freshwater Polygastrica and of Phytolitharia.

\section{List of References.}

(1) Nautical Magazine, 1839 , p. 364. The dust fell from the 9 th to the 13 th of February 1839 , whilst sailing from (lat. $10^{\circ} \mathrm{N}$., long. $29^{\circ} 59^{\prime}$ ) to (lat. $2^{\circ} 56^{\prime} \mathrm{N}$., long. $26^{\circ} 30^{\prime}$ W.). The wind on the 9 th was E.N.E., on the loth N.E. by E., and on the three succeeding days N.E.

(2) Geographical Journal, vol. vi. p. 296. "Survey of some of the Canary Islands and part of the coast of Africa, by Lieut. W. Arlett, R.N."

(3) Edinburgh New Phil. Journal, vol. xxxii. p. 134. The account is taken from Berghaus' Almanack of the dust which fell on the Princess Louise on Jan. 14th and 15 th, 1839 , between (lat. $24^{\circ} 20^{\prime}$ N., long. $26^{\circ} 42^{\prime}$ W.) and (lat. $23^{\circ} 05^{\prime} \mathrm{N}$., and long. $28^{\circ} 18^{\prime}$ W.): and again in 1840 from the 6 th to the 9 th of May, whilst between (lat. $10^{\circ} 29^{\prime}$ N., long. $32^{\circ} 19^{\prime}$ W.) and (lat. $16^{\circ} 44^{\prime}$ N., long. $36^{\circ} 37^{\prime}$ W.). During the 
voyage of a vessel of the same name, in which Dr. Meyen was a passenger (Reise um Erde, Th. i. s. 54) on the 27th of October 1830, the sails were observed to be stained by a powder, which Dr. Meyen considered to be a minute Cryptogamic plant: the date would lead me to believe that in this case the phænomenon was different from that of the dust described in this paper.

$\left({ }^{4}\right)$ Proceedings of the Geolog. Soc. vol. iv. p. 145. The dust described by the Rev. W. Clarke fell February 2 nd to the 4 th, 1839 , when between (lat. $21^{\circ} 14^{\prime}$ N., long. $25^{\circ} 6^{\prime} \mathrm{W}^{\prime}$.), and nearly (lat. $12^{\circ} 36^{\prime} \mathrm{N}$., long. $24^{\circ} 13^{\prime} \mathrm{W}$.). The direction of the wind has been already given in the paper; as it also has been, when the dust was collected by Lieut. James and myself. Mr. Clarke has since written a communication on the subject for the 'Tasmanian Journal' (vol. i. p. 321), to which I am indebted for two references.

$\left({ }^{5}\right)$ Nautical Magazine, 1838 , p. 824.

(6) Nautical Magazine, 1837, p. 291. Mr. Burnett, on February 12th to 15th, in sailing from (lat. $4^{\circ} 20^{\prime}$ N., long. $23^{\circ} 20^{\prime}$ W.) to (lat. $8^{\circ} \mathrm{N}$., long. $27^{\circ} 20^{\prime} \mathrm{W}$.), a distance of 300 miles, with the wind N.E., preceded by a S.E. squall which veered to E.S.E. and then to N.E., had the sails, rigging and mast covered with red dust. The dust began to fall as soon as the wind became N.E. : the atmosphere was very hazy. The nearest land was 600 miles distant. The same phænomenon was observed by Mr. Burnett in April 1836.

Mr. Forbes gives an account (Sharon Turner's S. Hist. of the World, p. 149) of dust which fell on a ship when 600 miles from the coast, between $C$. Verd and the R. Gambia : the wind all the previous night had been N.E.

In the Edinb. New Phil. Journal (vol. vii. p. 402) there is another account of dust which fell in considerable quantities on March $29 \mathrm{th}, 1821$, in lat. $11^{\circ} 3^{\prime} \mathrm{N}$., when 300 miles from the nearest part of Africa.

In Howard Malcolm's Travels (vol. ii. p. 200) there is a similar account of dust which fell during several days in February on a ship north of the equator, when more than 1000 miles from the coast of Africa : the wind was N.E.

(7) Horsburgh's East Indian Directory, p. 11.

(8) In Tuckey's Narrative of the Congo Expedition (p. 10), a discoloured sea and a hazy atmosphere are described on the 9 th of April in lat. $22^{\circ} \mathrm{N}$. and long. $19^{\circ}$ $9^{\prime} \mathrm{W}$., when 32 leagues from the main-land.

It may be worth here recording that Sir A. Burnes (Travels in Cabool, p. 223), in describing Khoten, a region of Upper Asia, adds, "it is said that its productiveness depends upon clouds of red dust, which always fall or are blown in this part of Asia." But he thinks that the statement requires confirmation.

\section{On two Species of Microscopic Shells found in the Lias. By H. E. Strickland, Esq., M.A., F.G.S.}

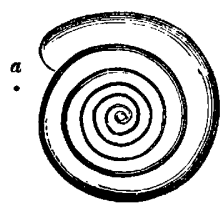

a. Orbis infimus, Strickland.

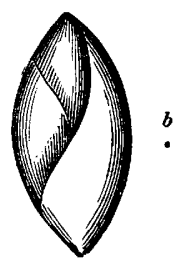

b. Polymorphina liassica, Strickland.

N.B. The figures are greatly magnified, the small dot beneath the letters being the natural size.

THE shells of the microscopic order Foraminifera, which occur so abundantly in the cretaceous and tertiary series, are found much more rarely as we descend through the secondary formations. Exam- 